\title{
Prediction of Stability Constants of Zinc(II) Complexes with 2-aminobenzamide and Amino Acids
}

\author{
Ante Miličević and Nenad Raos \\ Institute for Medical Research and Occupational Health, 10001 Zagreb, P.O.B. 291, Croatia \\ * Corresponding author: E-mail: antem @imi.hr \\ Tel.:+385 14682524; Fax: +38514673303
}

Received: 02-03-2015

\begin{abstract}
We developed a model for the stability $\left(\log \beta_{\mathrm{ZnLB}}\right)$ of $\mathrm{Zn}^{2+}$ mixed complexes $(N=16)$ with 2 -aminobenzamide $(\mathrm{L})$ and four amino acids (B) glycine, alanine, valine, and phenylalanine at 300, 310, 320, and $330 \mathrm{~K}$. The model based on the quadratic regression function of the molecular valence connectivity index of the third order, ${ }^{3} \chi^{v}$, yielded S.E. $=0.02$. We also developed an overall model for $K_{1}, K_{2}$ and $\beta_{\mathrm{ZnLB}}$ of the same system at all of the four temperatures $(N=48)$. This model yielded S.E. $=0.05$.
\end{abstract}

Keywords: coordination compounds, stability constants, graph-theoretical indices, regression models, models in chemistry

\section{Introduction}

Although models based on graph theoretical indices rely on somewhat vague concepts, as do other models based on topological approaches in theoretical chemistry, ${ }^{1,2}$ they have proved quite successful in many applications. Graph theoretical indices correlate well with many physicochemical parameters $^{3-6}$ and biological activities (QSAR). ${ }^{7,8}$ Our efforts to use topological indices, especially the valence connectivity index of the $3^{\text {rd }}$ order, ${ }^{3} \chi^{v}$, in order to build regression models for the prediction of stability constants of coordination compounds ${ }^{9}$ ended with varying success, depending on the nature of coordination compounds as well as on the quality of experimental data. Stability constants of copper(II) complexes with $\alpha$-amino acids were reproduced with such a precision that it was even possible to evaluate the results of two electroanalytical methods (GEP and SWV) used for their measurement. ${ }^{10}$ For copper(II) complexes with derivatives of thioflavin $\mathrm{T}$ and clioqiunol, used as model compounds for the study of Alzheimer's disease, we obtained even better results ${ }^{11}$ than those achieved by the more demanding DFT method. ${ }^{12}$ In some cases, our method, despite being strictly empirical, enabled the analysis of coordination, i.e. it gave insight into the structure of the complex..$^{13,14}$ However, in other cases additional variables ${ }^{15}$ and unusual forms of regression functions ${ }^{16}$ had to be introduced in or- der to obtain an acceptable agreement between theory and experiment.

The topic of this contribution are mixed zinc(II) complexes of 2-aminobenzamide (2-AB) with amino acids. These complexes have already been studied by $\mathrm{pH}$-metric and spectrophotometric methods, ${ }^{17}$ because 2-aminobenzamide and its derivatives have desirable pharmacological properties, ${ }^{18}$ and are also used as analytical reagents. ${ }^{19} \mathrm{On}$ the other hand, zinc(II) participates in many biological processes ${ }^{20}$ so the study of the above mentioned complexes should lead to a better understanding of the pharmacokinetics of 2-aminobenzamide and its derivatives.

Besides the model for stability $\left(\beta_{\mathrm{ZnLB}}\right)$ of mixed complexes of 2-aminobenzamide (L) with $\mathrm{Zn}^{2+}$ and four amino acids (B) glycine, alanine, valine, and phenylalanine at different temperatures $(300,310,320$, and $330 \mathrm{~K})$ :

$$
\beta_{\text {ZnLB }}=\frac{\left[\mathrm{ZnLB}^{+}\right]}{\left[\mathrm{Zn}^{2+}\right][\mathrm{L}]\left[\mathrm{B}^{-}\right]}
$$

we developed an overall model for $\beta_{\mathrm{ZnLB}}, K_{1}$ and $K_{2}$, defined as:

$$
K_{1}=\frac{\left[\mathrm{ZnB}^{+}\right]}{\left[\mathrm{Zn}^{2+}\right]\left[\mathrm{B}^{-}\right]}
$$




$$
K_{2}=\frac{\left[\mathrm{ZnLB}^{+}\right]}{\left[\mathrm{ZnL}^{2+}\right]\left[\mathrm{B}^{-}\right]}
$$

\section{Methods}

\section{1. Calculation of Topological Indices}

We calculated topological indices using the E-DRAGON program system, developed by R. Todeschini and coworkers, capable of yielding 119 topological indices in a single run, along with many other molecular descriptors. ${ }^{21,22}$ Connectivity matrices were constructed with the aid of the Online SMILES Translator and Structure File Generator. ${ }^{23}$

The valence molecular connectivity index of the $3^{\text {rd }}$ order, ${ }^{3} \chi^{v}$, was defined as: ${ }^{24-27}$

$$
{ }^{3} \chi^{v}=\sum_{\text {path }}[\delta(i) \delta(j) \delta(k) \delta(l)]^{-0.5}
$$

where $\delta(i), \delta(j), \delta(k)$, and $\delta(l)$ are weights (valence values) of vertices (atoms) $i, j, k$, and $l$ making up the path of

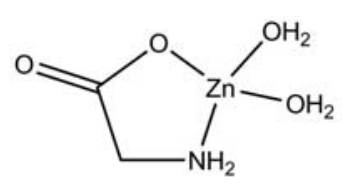

$\mathrm{ZnB}$

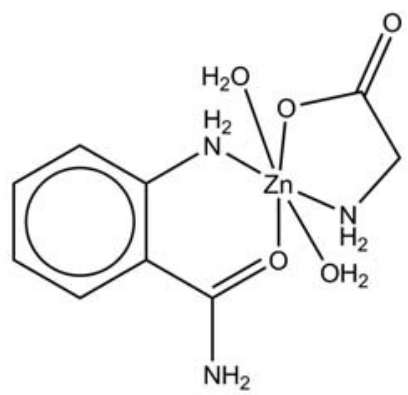

$\mathrm{ZnLB}$
Figure 1. Constitutional formulas of $\mathrm{Zn}$ (II) tetracoordinated monocomplexes with glycine (B) and hexacoordinated mixed complex with 2-aminobenzamide (L) and glycine (B) length 3 (three consecutive chemical bonds) in a vertexweighted molecular graph. The valence value, $\delta(i)$, of a vertex $i$ is defined by:

$$
\delta(i)=\left[Z^{v}(i)-H(i)\right] /\left[Z(i)-Z^{v}(i)-1\right]
$$

where $Z^{\prime}(i)$ is the number of valence electrons belonging to the atom corresponding to vertex $i, Z(i)$ is its atomic number, and $H(i)$ is the number of hydrogen atoms attached to it.

The ${ }^{3} \chi^{v}$ index for all mono- and mixed complexes was calculated from the graph representations of aquacomplexes (Fig. 1), assuming that the metal in the monocomplexes is tetracoordinated and in mixed complexes hexacoordinated.

\section{2. Regression Calculations}

Regression calculations, including the leave-one-out procedure (LOO) of cross validation were done using the CROMRsel program. ${ }^{28}$ The standard error of the cross-validation estimate was defined as:

$$
\mathrm{S}_{\mathrm{e}} \mathrm{cv}_{\mathrm{cv}}=\sqrt{\sum_{i} \frac{\Delta X_{i}^{2}}{N}}
$$

where $\Delta X$ and $N$ denotes cv residuals and the number of reference points, respectively.

\section{Results}

In order to model the logarithm of stability constant, $\log \beta_{\mathrm{ZnLB}}$, (Eq. 1, Table 1) of mixed $\mathrm{Zn}^{2+}$ complexes with 2 -aminobenzamide and amino acids ( $\mathrm{ZnLB})$, we used the

\begin{tabular}{|c|c|c|c|c|c|c|}
\hline Temperature (K) & Amino acid (B) & $\log K_{1}$ & $\log K_{2}$ & $\log \beta_{\mathrm{ZnLB}}$ & ${ }^{3} \chi^{\prime}(\mathrm{ZnB})$ & ${ }^{3} \chi^{\prime \prime}(\mathrm{ZnLB})$ \\
\hline \multirow[t]{4}{*}{300} & Gly & 4.96 & 5.29 & 9.13 & 1.748 & 5.770 \\
\hline & Ala & 4.89 & 5.13 & 8.97 & 2.148 & 6.082 \\
\hline & Val & 4.59 & 4.83 & 8.67 & 2.599 & 6.533 \\
\hline & Phe & 4.46 & 4.68 & 8.52 & 3.581 & 7.195 \\
\hline \multirow[t]{4}{*}{310} & Gly & 4.84 & 5.22 & 8.95 & 1.748 & 5.770 \\
\hline & Ala & 4.76 & 5.06 & 8.79 & 2.148 & 6.082 \\
\hline & Val & 4.46 & 4.80 & 8.53 & 2.599 & 6.533 \\
\hline & Phe & 4.33 & 4.66 & 8.39 & 3.581 & 7.195 \\
\hline \multirow[t]{4}{*}{320} & Gly & 4.73 & 5.18 & 8.81 & 1.748 & 5.770 \\
\hline & Ala & 4.65 & 5.01 & 8.64 & 2.148 & 6.082 \\
\hline & Val & 4.36 & 4.73 & 8.36 & 2.599 & 6.533 \\
\hline & Phe & 4.24 & 4.59 & 8.22 & 3.581 & 7.195 \\
\hline \multirow[t]{4}{*}{330} & Gly & 4.61 & 5.08 & 8.63 & 1.748 & 5.770 \\
\hline & Ala & 4.56 & 4.94 & 8.49 & 2.148 & 6.082 \\
\hline & Val & 4.23 & 4.67 & 8.22 & 2.599 & 6.533 \\
\hline & Phe & 4.13 & 4.54 & 8.09 & 3.581 & 7.195 \\
\hline
\end{tabular}
quadratic function of ${ }^{3} \chi^{v}$ (Figure 2):

Table 1. Experimental stability constants $\log K_{1}, \log K_{2}$ and $\log \beta_{\mathrm{ZnLB}}$ [17] and ${ }^{3} \chi^{v}$ index of $\mathrm{Zn}(\mathrm{II})$ complexes with 2-aminobenzamide (L) and amino acids (B) ... 


$$
\log \beta_{\mathrm{ZnLB}}=a_{1}\left[^{3} \chi^{v}(\mathrm{ZnLB})\right]+a_{2}\left[{ }^{3} \chi^{v}(\mathrm{ZnLB})\right]^{2}+b
$$

because it proved better than the linear function (e.g. at $300 \mathrm{~K}$, S.E. $=0.04$ and 0.06 for quadratic and linear function, respectively; $N=4$ ).

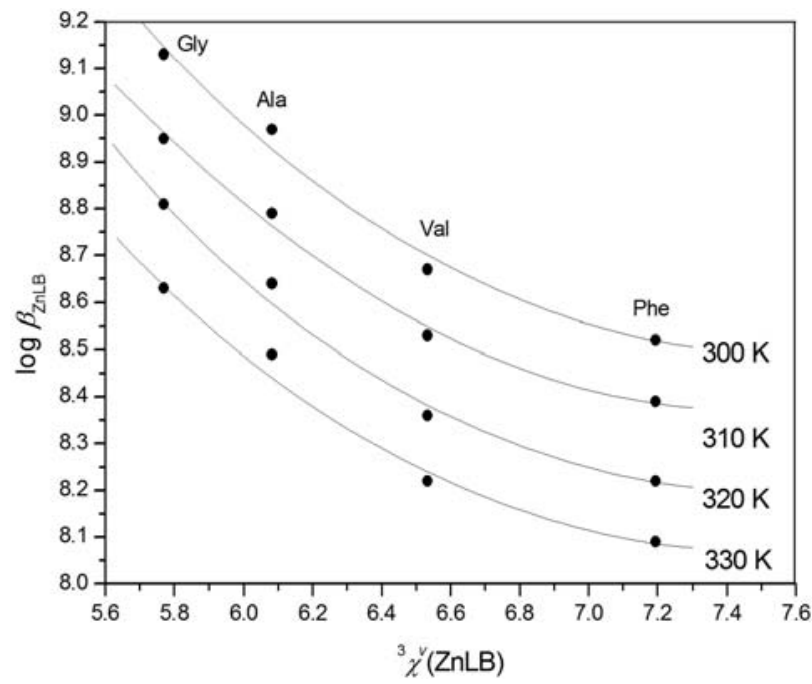

Figure 2. Quadratic dependence of $\log \beta_{\mathrm{ZnLB}}$ of mixed $\mathrm{Zn}^{2+}$ complexes with 2-aminobenzamide and amino acids ( $\mathrm{ZnLB})$ on their ${ }^{3} \chi^{v}$ index, at four temperatures.

As the dependence of $\log \beta_{\mathrm{ZnLB}}$ on temperature in the range $300-330 \mathrm{~K}$ is linear, ${ }^{17}$ we proposed the model for all four of the temperatures $(N=16)$ simply by including temperature into Eq. (7):

$$
\begin{aligned}
\log \beta_{\mathrm{ZnLB}}= & \left.a_{1}{ }^{3} \chi^{v}(\mathrm{ZnLB})\right]+a_{2}\left[{ }^{3} \chi^{v}(\mathrm{ZnLB})\right]^{2}+ \\
& +a_{3} T+b
\end{aligned}
$$

where $T$ is the absolute temperature at which constants, $\log \beta_{\mathrm{ZnLB}}$, were measured. The model yielded S.E. ${ }_{\mathrm{cv}}=$ 0.03 (Model 1, Table 2).

The values of $\log K_{1}$ and $\log K_{2}$ (Eqs. 2 and 3) show the same quadratic dependence on ${ }^{3} \chi^{v}$ (Figure 3). This enabled the development of the model $(N=12)$ for all of the constants at a given temperature:

$$
\log K=a_{1}^{3} \chi^{v}+a_{2}\left[{ }^{3} \chi^{v}\right]^{2}+a_{3}\left[\log K_{0}\right]+b
$$

where $K$ denotes $K_{1}, K_{2}$ and $\beta_{\mathrm{ZnLB}} ; K_{0}$ are the correspon- ding stability constants of a referent complexes (either with glycine, alanine, valine, or phenylalanine); ${ }^{3} \chi^{v}$ denotes ${ }^{3} \chi^{v}(\mathrm{ZnB})$ in the case of $K_{1}$ constant and for $K_{2}$ and $\beta_{\mathrm{ZnLB}}$ it corresponds to ${ }^{3} \chi^{v}(\mathrm{ZnLB})$ normalized on ${ }^{3} \chi^{v}(\mathrm{Zn}$ Gly):

$$
{ }^{3} \chi^{v}={ }^{3} \chi^{v}(\mathrm{ZnLB})-\left[{ }^{3} \chi^{v}(\mathrm{ZnLGly})-{ }^{3} \chi^{v}(\mathrm{ZnGly})\right]
$$

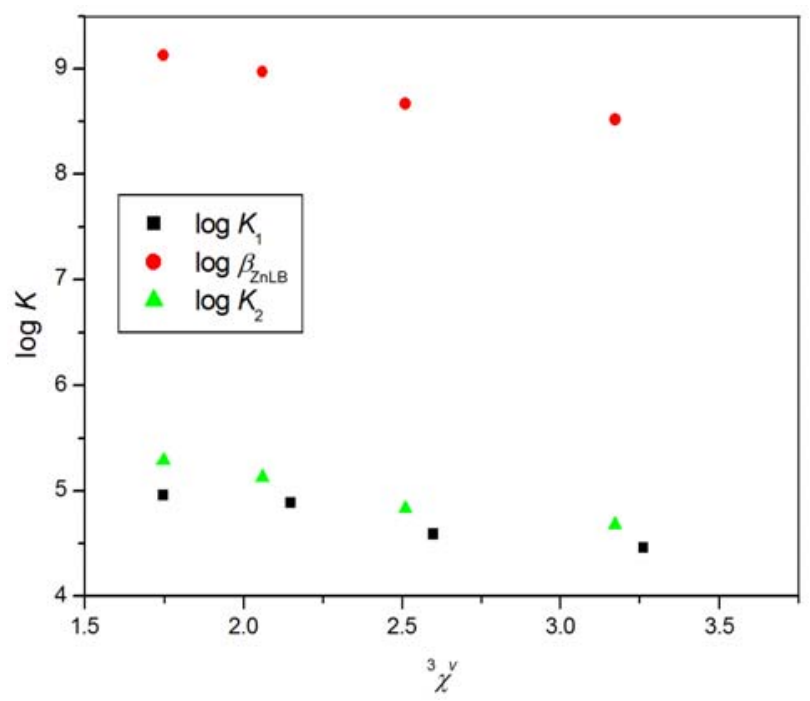

Figure 3. The dependence of $\log K\left(\log K_{1}, \log K_{2}\right.$ and $\left.\log \beta_{\mathrm{ZnLB}}\right)$ on ${ }^{3} \chi^{v}$ at $300 \mathrm{~K} ;{ }^{3} \chi^{v}$ denotes ${ }^{3} \chi^{v}(\mathrm{ZnB})$ in the case of $K_{1}$ constant and for $K_{2}$ and $\beta_{\mathrm{ZnLB}}$ constants ${ }^{3} \chi^{v}$ is ${ }^{3} \chi^{v}(\mathrm{ZnLB})$ normalized on ${ }^{3} \chi^{v}(\mathrm{Zn}-$ B), Eq. (10).

Taking glycine complexes as referent, the model gave S.E. cv $_{\text {c }} 0.09$ (Model 2, Table 2).

The same function, Eq. (9), can be applied to $K_{1}, K_{2}$ and $\beta_{\mathrm{ZnLB}}$ at all four of the temperatures $(N=48)$. In this case, $K_{0}$ denotes the corresponding stability constants of a referent complexes at all of the temperatures. Taking glycine complexes as referent, the model gave $S . E_{c v}=$ 0.06 (Model 3, Table 2).

Furthermore, we have found that it is possible to make the model more predictive. To be more precise, it is enough to know the $K_{0}$, i.e. $K_{1}, K_{2}$ and $\beta_{\mathrm{ZnLB}}$ constants of a referent complex at only two temperatures. The $K_{0}$ values at the other two temperatures can be then easily cal-

\begin{tabular}{|c|c|c|c|c|c|c|c|c|c|}
\hline \multirow{2}{*}{$\begin{array}{l}\text { Model } \\
\text { (Eq.) }\end{array}$} & \multirow{2}{*}{$\begin{array}{l}\text { Stability } \\
\text { constant }\end{array}$} & \multirow{2}{*}{$N$} & \multicolumn{4}{|c|}{ Regression coefficients } & \multirow[b]{2}{*}{$r$} & \multirow{2}{*}{ S.E. } & \multirow{2}{*}{ S.E. ${ }_{c v}$} \\
\hline & & & $a_{1}$ (S.E.) & $a_{2}($ S.E.) & $a_{3}$ (S.E.) & $b$ (S.E.) & & & \\
\hline $1(8)$ & $\beta_{\mathrm{ZnLB}}$ & 16 & $-3.22(41)$ & $0.216(32)$ & $-0.0155(6)$ & $25.2(13)$ & 0.9960 & 0.02 & 0.03 \\
\hline $2(9)$ & $K_{1}, K_{2}, \beta_{\mathrm{ZnLB}}$ & 12 & $-1.26(43)$ & $0.171(87)$ & $0.987(11)$ & $1.78(52)$ & 0.9995 & 0.06 & 0.08 \\
\hline $3(9)$ & $K_{1}, K_{2,} \beta_{\mathrm{ZnLB}}$ & 48 & $-1.22(17)$ & $0.167(34)$ & $0.9880(43)$ & $1.72(20)$ & 0.9996 & 0.05 & 0.06 \\
\hline
\end{tabular}
culated from the linear dependence of $K_{1}, K_{2}$ and $\beta_{\mathrm{ZnLB}}$ on $T$. This way, fewer experimental constants are needed for

Table 2. Regression models for the estimation of stability constants $\log K_{1}, \log K_{2}$ and $\log \beta_{\mathrm{ZnLB}}$ of $\mathrm{Zn}$ (II) complexes with 2-aminobenzamide (L) and amino acids (B) 


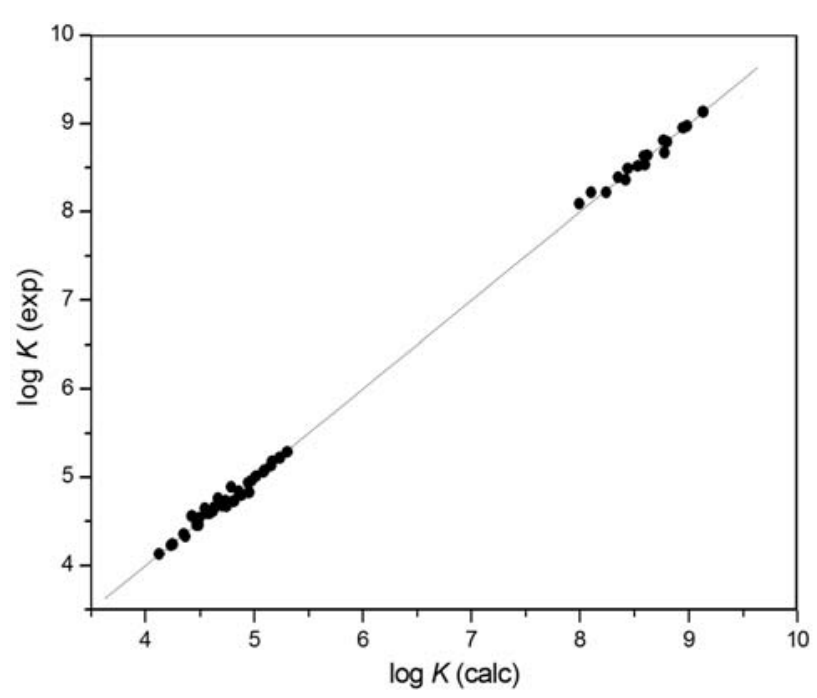

Figure 4. Experimental vs. calculated values of $K\left(K_{1}, K_{2}\right.$ and $\beta_{\mathrm{Zn}-}$ ${ }_{\mathrm{LB}}$ ) by Eq. (9), where $K$ refer to the stability of glycine complexes at 300 and $310 \mathrm{~K}$. The model yielded $r=0.9996$, S.E. $=0.05$, S.E. ${ }_{\mathrm{cv}}=0.06$.

calibration. Such a model, calibrated on $K_{1}, K_{2}$ and $\beta$ of glycine complexes at 300 and $310 \mathrm{~K}$, yielded S.E. ${ }_{\mathrm{cv}}=$ 0.06 (Figure 4).

\section{Conclusion}

We developed two kinds of models. A model for the prediction of stability $\left(\log \beta_{\mathrm{ZnLB}}\right.$ ) of $\mathrm{Zn}^{2+}$ mixed complexes with 2-aminobenzamide (L) and four amino acids (B) at four temperatures $(N=16)$, and a model for the prediction of $K_{1}, K_{2}$ and $\beta_{\mathrm{ZnLB}}$ of the same system $(N=48)$. In both cases, the theoretical results showed excellent agreement with the experimental ones, yielding errors commensurable with the errors of measurements. Specifically, the maximal differences between the experimental and theoretical (cross-validated) values were 0.06 and 0.15 for the two models (Models 1 and 3, Table 2), respectively, while the declared standard error of measurements were $0.03-0.08$ for $\log K_{1}$ and $0.03-0.09$ for $\log \beta_{\mathrm{ZnLB}}$.

It should also be pointed out that the $\log K_{1}$ function has the same form as the function for copper(II) monocomplexes with amino acids. ${ }^{29}$

\section{References}

1. P. L. Ayers, R. J. Boyd, P. Bultinck, M. Caffarel, R. CarbóDorca, M. Causá, J. Cioslowski, J. Contreras-Garcia, D. L. Cooper, P. Coppens, C. Gatti, S. Grabowski, P. Lazzeretti, P. Macchi, A. M. Pendás, P. L. A. Popelier, K. Ruedenberg, H. Rzepa, A. Savin, A. Sax, W. H. E. Schwarz, S. Shahbazian, B. Silvi, M. Solà, V. Tsirelson, Comput. Theor. Chem. 2015,
1053, 2-16. http://dx.doi.org/10.1016/j.comptc.2014.09.028

2. E. V. Babaev, Intuitive chemical topology concepts, in: D. Bonchev, R. Rouvray, (Eds.), Chemical Topology: Introductions and Fundamentals, Gordon and Breach, Reading, 1999, pp. 167-264.

3. Z. Mihalić, N. Trinastić, J. Chem. Educ. 1992, 69, 701-712. http://dx.doi.org/10.1021/ed069p701

4. B. Lučić, S. Nikolić, N. Trinajstić, Croat. Chem. Acta 1995, 68, 417-434.

5. E. V. Konstantinova, M. V. Diudea, Croat. Chem. Acta 2000, 73, 383-403.

6. M. Randić, S. C. Basak, M. Pompe, M. Novič, Acta Chim. Slov. 2001, 48, 169-180.

7. L. H. Hall, L. B. Kier, Eur. J. Med. Chem. 1981, 16, 399407.

8. S. Bajaj, S. S. Sambi, A. K. Madan, Croat. Chem. Acta 2005, 78, 165-174.

9. N. Raos, A. Miličević, Arh. Hig. Rada Toksikol. 2009, 60, 123-128. http://dx.doi.org/10.2478/10004-1254-60-2009-1923

10. N. Raos, G. Branica, A. Miličević, Croat. Chem. Acta 2008, 81, 511-517.

11. A. Miličević, N. Raos, Arh. Hig. Rada Toksikol. 2013, 64, 539-545. http://dx.doi.org/10.2478/10004-1254-64-2013-2418

12. A. Rimola, J. Alí-Torres, C. Rodríguez- Rodríguez, J. Poater, E. Matito, M. Solá, M. Sodupe, J. Phys. Chem. A 2011, 115, 12659-12666. http://dx.doi.org/10.1021/jp203465h

13. A. Miličević, N. Raos, Acta Chim. Slov. 2012, 59, 194-198.

14. A. Miličević, N. Raos, General model based on connectivity index ${ }^{3} \chi^{v}$ for the prediction of stability constants of copper(II) complexes with $\alpha$-amino acids, in: I. Gutman (Ed.), Topics in Chemical Graph Theory, Univ. Kragujevac, Kragujevac, 2014, pp. 193-204.

15. A. Miličević, N. Raos, Acta Chim. Slov. 2014, 61, 904-908.

16. A. Miličević, N. Raos, Croat. Chem. Acta 2009, 82, 633-639.

17. J. Dharmaraja, P. Subbaraj, T. Esakkidurai, S. Shobana, S. Raji, Acta Chim. Slov. 2014, 61, 803-812.

18. D. Oltmanns, M. Eisenhut, W. Mier, U. Heberkorn, Curr. Med. Chem. 2009, 16, 2086-2094.

http://dx.doi.org/10.2174/092986709788612684

19. S. B. Katiyar, I. Bansal, J. K. Saxena, P. M. Chauhan, Bioorg. Med. Chem. Lett. 2005, 15, 47-50.

http://dx.doi.org/10.1016/j.bmcl.2004.10.046

20. B. L. Vallee, K. H. Falchuk, Physiol. Rev. 1993, 73, 79-118.

21. I. V. Tetko, J. Gasteiger, R. Todeschini, A. Mauri, D. Livingstone, P. Ertl, V. A. Palyulin, E. V. Radchenko, N. S. Zefirov, A. S. Makarenko, V. Y. Tanchuk, V. V. Prokopenko, , J. Comput. Aid. Mol. Des. 2005, 19, 453-63. http://dx.doi.org/10.1007/s10822-005-8694-y

22. VCCLAB, Virtual Computational Chemistry Laboratory, http://www.vcclab.org, 2005.

23. http://cactus.nci.nih.gov/services/translate/

24. L. B. Kier, L. H. Hall, J. Pharm. Sci. 1976, 65, 1806-1809. http://dx.doi.org/10.1002/jps.2600651228

25. L. B. Kier, L. H. Kall, Molecular Connectivity in Structure- 
Activity Analysis, Willey, New York, 1986.

26. L. B. Kier, L. H. Hall, Molecular Connectivity in Chemistry and Drug Research, Academic Press, New York, 1976.

27. M. Randić, MATCH Commun. Math. Comput. Chem. 2008, 59, 5-124.
28. B. Lučić, N. Trinajstić, J. Chem. Inf. Comput. Sci. 1999, 39, 121-132. http://dx.doi.org/10.1021/ci980090f

29. A. Miličević, N. Raos, Chin. J. Chem. 2011, 29, 1800-1804. http://dx.doi.org/10.1002/cjoc.201180316

\section{Povzetek}

Razvili smo model za stabilnost $\left(\log \beta_{\mathrm{ZnLB}}\right) \mathrm{Zn}^{2+}$ mešanih kompleksov $(N=16) \mathrm{z}$ 2-aminobenzamidom $(\mathrm{L})$ in štirimi amino kislinami (B): glicinom, alaninom, valinom in fenilalaninom pri 300, 310, 320 in $330 \mathrm{~K}$. Model je osnovan na kvadratni regresijski funkciji molekularnega indeksa valenčne povezljivosti tretjega reda, ${ }^{3} \chi^{v}$. Za isti sistem smo postavili tudi splošni model za $K_{1}, K_{2}$ in $\beta_{\mathrm{ZnLB}}$ pri vseh temperaturah. 